\title{
VÁROSI KORMÁNYZÁS
}

Néhány éve tudományos, szakmai, szakpolitikai tanácskozásokon, s a szakirodalomban gyakran elhangzó kijelentés, hogy a város fontos (the city matters).

Miért kell ezt bizonygatni? A város természetesen fontos, hiszen a fỏld népességének mára már nagyobb része a városokban él.

A városok szerepének felértékelődése, a városnövekedés elsősorban a nagyvárosok bázisán történik, melyek rendkívuil erős hatást gyakorolnak a gazdaságra, az életmódra és a regionális fejlödésre. A városok térbeli szerepét illetően mindig is megkülönböztető vonás volt a kifelé sugárzás, a környék vonzása és ellátása, a térbeli kapcsolatok, mégis csak a legutóbbi évtizedekben ismerhető fel a városi hálózatok markáns térstrukturáló funkciója.

Míg a kilencvenes években a regionalizmus jelentette a kihívást mind a gazdaságfejlesztés, mind az uniós kohéziós politika számára, addig az ezredfordulót követően gyakrabban hangzik el szakpolitikai fórumokon a városi hálózatokra, pólusokra épülő regionális fejlődés igénye, szükségessége. Az Európai Unió kohéziós politikájában bekövetkezett fordulat is erőteljesen épít a városok versenyképességi potenciáljára.

A területi kormányzati/igazgatási rendszerek meglehetősen késve reagálnak a térben, illetve a városok szerepében bekövetkezỏ változásokra. Az Európai Unió tagországaiban jellemzően a regionalizmus jegyében zajlottak, zajlanak területi reformok, miközben napjainkra már a városi reneszánsz kihívásaira lenne fontos igazgatási megoldásokat találni.

A Tér és Társadalom tematikus száma, felismerve a téma aktualitását, a városi kormányzás kérdéskörével foglalkozik. A szerzők ismert igazgatási szakértők, urbanisták, akik igyekeztek a városi irányítás nemzetközi modelljeit bemutatni, értékelni a hazai fejleményeket, szükségleteket.

A városi kormányzás nem tekinthető slágertémának hazánkban, nem véletlen, hogy viszonylag kevés empirikus kutatás zajlott a városi önkormányzatok körében. Ennek vélhetően az is oka, hogy a közpolitika figyelmét is elkerülte a városok kormányzási teljesítménye. Érdekes módon az önkormányzati rendszer átalakítási elképzelései között sem szerepel súlyponti helyen a városi igazgatás modernizálása.

A fentiek alapján a TÉT vállalkozása aktuálisnak és úttörőnek is tekinthető, s remélhetően megindít egy, a korábbihoz képest intenzívebb és koncentráltabb vitát a városok jövőbeni kormányzását illetően.

Pálné Kovács Ilona vendégszerkesztó 